\title{
Introduction to Tractate Ševu'ot
}

The Tractate "Oaths" has two parts. The first three chapters are ritualistic, the later five are partially legalistic. The ritualistic part is based on Lev. $5: 1-13,20-26$, detailing the sacrifices required for rash or senseless as well as false oaths. Since Lev. 5:1-13 states the same treatment for infringements of the purity of the Temple or of sacrifices as for rash or senseless oaths, the first Chapter, after an introduction listing matters which can be classified as "two kinds which split into four cases", treats inadvertent impurity of sacrifices and their atonement, whether by sacrifice or the Temple service of the Day of Atonement. The Second Chapter then defines the places which can claim the holiness of the Temple and require atonement for inadvertent violations of its purity.

The third Chapter starts with an enumeration of the two/four ways in which a non-judicial oath can be irrelevant or false, whether by one's own initiative or formulated by others. The oaths are punishable by flogging if made before witnesses after due warning, or sacrifices following the same rules as infringements of purity if inadvertent.

The Fourth Chapter deals with oaths which serve as subpoenas to testify. The basic situation is that A says to B I put an oath or an imprecation on you that you should come and testify for me. If B agrees by saying "Amen" and then reneges on his duty, he has violated the oath as described in Lev. 5:1. These oaths can be imposed in or out of Court. The Chapter ends with a discussion of the use of substitutes for the Divine name in imprecations.

Chapter Five deals with the oaths by which people falsely defend themselves against monetary claims (Lev. 5:21-26). While the doctrines of judicial proof are detailed in Tractates Neziqin and Ketubot, the Chapter mainly deals with the obligations for sacrifices, with an appendix about the rules by which judicial fines can be imposed. 
Chapter Six treats oaths imposed by the court on a defendant in a case in which he partially admits claims not proven by documents or witnesses. $\mathrm{He}$ has to swear that he does not owe the part of the claim which he disputes. The oath cannot be imposed if either the defendant rejects the claim in its entirety, when the claimant has to provide proof by witnesses or documents, or if the defendant rejects the claim but admits an unrelated one. Also, matters that must be documented such as real estate claims cannot be settled by oath.

Chapter Seven deals with rabbinic oaths instituted in the interest of social justice, such as the power of the worker to claim unpaid wages by an oath without having to produce witnesses, or cases involving a widow and her husband's heirs, or dissolutions of partnerships, where documents proving exact accounting may be difficult or impossible to obtain.

Finally, Chapter Eight treats the biblical oaths imposed on trustees in case a deposit was damaged or lost, Ex. 22:6-14. Since these rules are treated at length in Tractate Neziqin, the corresponding Chapter in the Babli is very short. Since the treatment in the Yerushalmi Neziqin is so very short, the Chapter here is more substantial than its Babli counterpart. 